\title{
HIRUNDO RUSTICA RUSTICA AT HERSCHEL ISLAND-QIKIQTARUK, YUKON- A BARN SWALLOW SUBSPECIES NEW TO CANADA
}

\author{
CAMERON D. ECKERT, Yukon Parks, Department of Environment, \\ Yukon Government, P.O. Box 2703, Whitehorse, Yukon Y1A 2C6; \\ cameron.eckert@gov.yk.ca \\ RICHARD R. GORDON, Yukon Parks, Department of Environment, Yukon \\ Government, Inuvik, Northwest Territories
}

\begin{abstract}
At least three of the 19 Barn Swallows recorded on Herschel Island-Qikiqtaruk, along the Arctic coast of the Yukon Territory, represent the whitebellied Old World subspecies Hirundo rustica rustica. The birds were photographed on 3 July 2010, 24 July 2015, and 19-20 June 2019. These first Canadian records are complemented by five from northern Alaska, west to Utqiagivik (Barrow). This subspecies breeds in Europe, Africa, and northwestern Asia, east to the Yenisei River. The lack of Alaska records of H. r. rustica to the west of Utqiagivik and of Canadian records east of Qikiqtaruk suggest that these vagrants reached the New World not by orienting or drifting at the wrong angle but by overshooting their normal spring migration path, following a nearly polar great-circle route.
\end{abstract}

Extralimital birds can reveal unexpected connections among disparate places, they can challenge presumptions as to how birds move around the globe, and they can signal wide-scale ecological change. Herschel IslandQikiqtaruk $\left(69.6^{\circ} \mathrm{N}, 139.1^{\circ} \mathrm{W}\right)$, a Yukon territorial park of $116 \mathrm{~km}^{2}$ located $5 \mathrm{~km}$ off the Yukon's Arctic coast, in northwestern Canada, has been a site for many extralimital birds over the years (Sinclair et al. 2003, Cooley et al. 2012, Burn 2012). Here we report on occurrences of the Barn Swallow (Hirundo rustica) at Qikiqtaruk, including Canada's first records of nominate H. r. rustica.

Up to eight subspecies of the Barn Swallow are recognized (Dickinson and Christidis 2014), of which three are known from northwestern North America: H. r. erythrogaster (breeds North and South America), H. r. rustica (Europe), and H. r. gutturalis (Asia). These subspecies can be distinguished by the shape and color of the throat patch, ventral plumage color, breast-band width, and tail length (Turner and Rose 1989, Turner 2006, Robinson and DeCicco 2017, Brown and Brown 2019). Nominate rustica is white below, has a broad dark blue-black and generally unbroken breast band (which can variably show some rufous feathers), a relatively longer tail, and a more restricted rufous throat patch; H. r. erythrogaster is rufous below, has a narrower breast band restricted to the sides of the breast with a broad wash of rufous in the middle, a more extended rufous throat patch, and is shorter tailed; H. r. gutturalis appears somewhat intermediate but is usually notably paler below than H. r. erythrogaster. Extralimital individuals intermediate in features might not be identifiable to subspecies, and rufous-bellied birds are generally assumed to be erythrogaster. Genetic analyses have shown erythrogaster and gutturalis to be closely related, while nominate rustica is more distant genetically and was considered a distinct species by Turner (2006) and Zink et al. (2006). In identifying Barn Swallows at Qikiqtaruk we referred to the primary identification references (Turner and Rose 1989, Turner 2006, Robinson and DeCicco 2017, 
Brown and Brown 2019), as well as to the extensive catalog of georeferenced photos available through the Macaulay Library (https://eBird.org).

The Asiatic subspecies gutturalis occurs casually in coastal western Alaska (Kessel and Gibson 1978, Gibson and Withrow 2015, Lehman 2019) and bred at Nome in 2016 (Robinson and DeCicco 2017). There are no definitive records of $H$. r. gutturalis in northern Alaska, where H. r. rustica has been documented by two specimen records and two photographic records at Utqiagivik (Barrow), and one photographic record at the Colville River delta (Kessel and Gibson 1978, Gibson and Withrow 2015, Robinson and DeCicco 2017, https://eBird.org).

\section{BARN SWALLOWS AT QIKIQTARUK}

The Barn Swallow is a rare but regular wanderer to the Beaufort Sea region with records across the Yukon's north slope. Nesting has been confirmed at Clarence Lagoon (Johnson and Herter 1989, Sinclair et al. 2003). At Qikiqtaruk the species is a casual visitor with 19 records, of which six represent the American subspecies erythrogaster, two were confirmed to be of H. r. rustica, and one was suggestive of H. r. rustica (Table 1). In May 2015, Eckert exam-

TABLE 1 Records of the Barn Swallow at Herschel Island-Qikiqtaruk Territorial Park

\begin{tabular}{|c|c|c|c|c|}
\hline Date & Subspecies $^{a}$ & Documentation & Observers & Source ${ }^{b}$ \\
\hline 14 July 1987 & unknown & sight record & D. Canning & S12050890 \\
\hline 19 July 1996 & unknown & sight record & C. Gordon, A. Tardiff & S60870391 \\
\hline 15 July 1998 & unknown & sight record & C. Gordon & S60870440 \\
\hline 21 June 2001 & unknown & sight record & P. Foisy & S60870752 \\
\hline 29 June 2006 & unknown & sight record & M. Boothroyd & S40121919 \\
\hline 23 June 2007 & erythrogaster & sight record & C. Eckert & S25927598 \\
\hline 16 June 2008 & unknown & sight record & R. Gordon & S60870792 \\
\hline 3 July 2010 & rustica $^{c}$ & photo & $\begin{array}{l}\text { S. McLeod, } \\
\text { L. J. Meyook }\end{array}$ & S60869695 \\
\hline 3 July 2010 & unknown & photo & $\begin{array}{l}\text { S. McLeod, } \\
\text { L. J. Meyook }\end{array}$ & S60869695 \\
\hline 24 June 2015 & rustica & photo & C. Eckert & S25690325 \\
\hline 25 June 2015 & erythrogaster & sight record & C. Eckert & S25690400 \\
\hline 12-14 June 2016 & erythrogaster & photo/specimen ${ }^{d}$ & C. Eckert & S33927325 \\
\hline 12 June 2016 & uncertain & photo & C. Eckert & S33927325 \\
\hline 28 May 2018 & unknown & sight record ${ }^{e}$ & S. Goeson, R. Joe & S60871680 \\
\hline 10 June 2019 & erythrogaster & photo & C. Eckert & S57551123 \\
\hline 16-20 June 2019 & erythrogaster & photo & C. Eckert & S57545349 \\
\hline 19-20 June 2019 & erythrogaster & photo & C. Eckert & S57542914 \\
\hline 19-20 June 2019 & rustica & photo & C. Eckert & S57542914 \\
\hline
\end{tabular}

${ }^{a}$ Unknown indicates records for which there is no note of subspecies, while uncertain indicates records for which photos exist but are inadequate to confirm the subspecies.

${ }^{b}$ Number of eBird checklist, accessible as "https://ebird.org/checklist/S...."

'Photos of this individual, though suggesting nominate rustica, left uncertainty in subspecies identification.

${ }^{d}$ Yukon College M-28-13.

${ }^{e}$ Two individuals. 


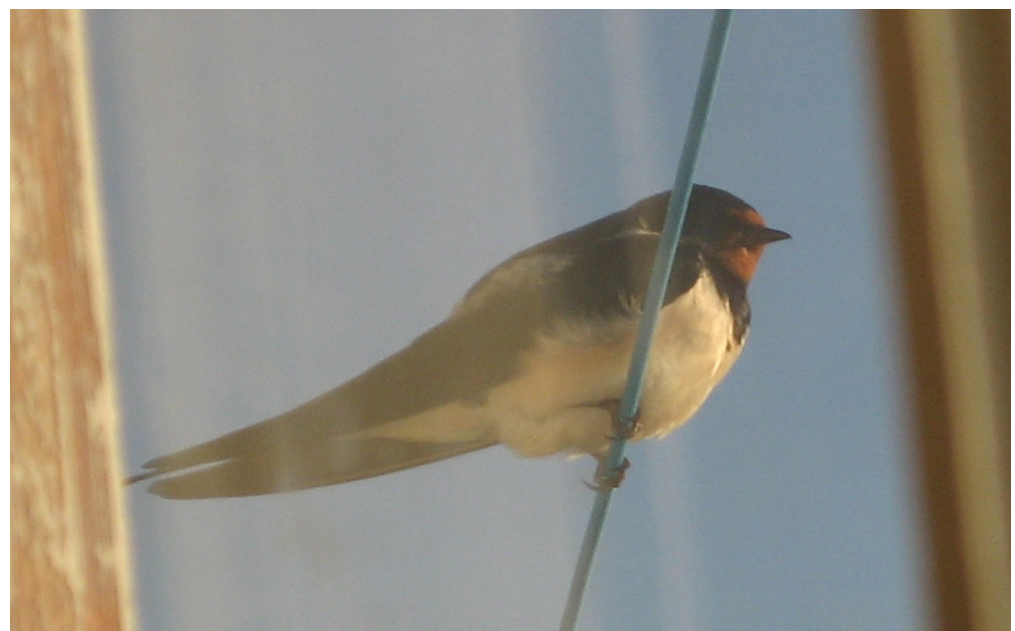

FIgURE 1. A Barn Swallow at Qikiqtaruk 3 July 2010 with a solid dark breast band and long tail (shown in other photos), suggesting H. r. rustica though with some uncertainty.

\section{Photo by Samuel McLeod and LeeJohn Meyook}

ined photos taken 3 July 2010 of a pale-bellied bird with a complete thick blue-black neck band, a relatively long tail, and a relatively restricted rufous throat patch consistent with nominate rustica (Figure 1). However, the photos left some uncertainty in the identification and so this record is noted with question mark (Table 1). On 24 June 2015, Eckert saw a Barn Swallow that flashed a bright white belly, undertail, and wing lining. It had a thick and

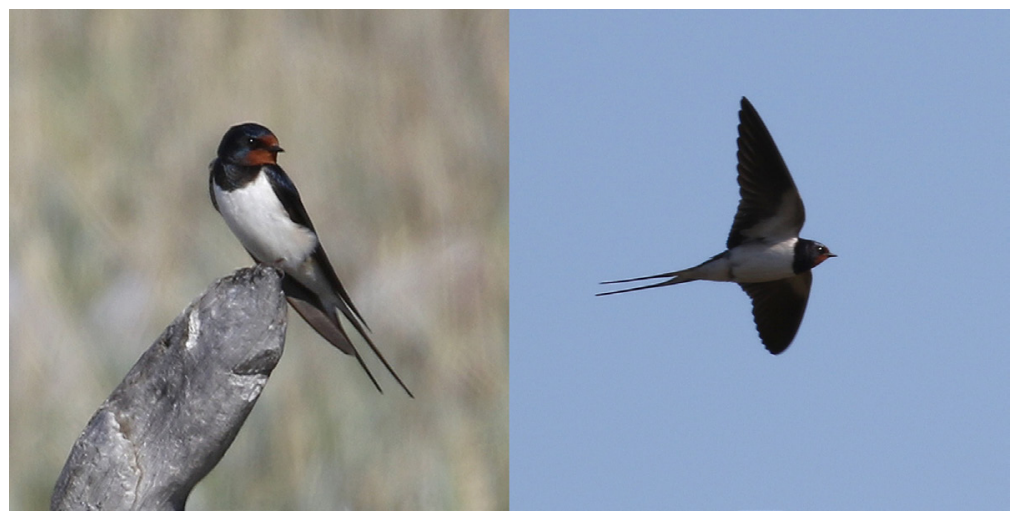

Figure 2. Male Barn Swallow (H. r. rustica) at Qikiqtaruk on 24 June 2015 with bright white undersides, a broad dark and unbroken breast band, relatively small rufous throat patch, and very long tail streamers.

Photos by Cameron D. Eckert 


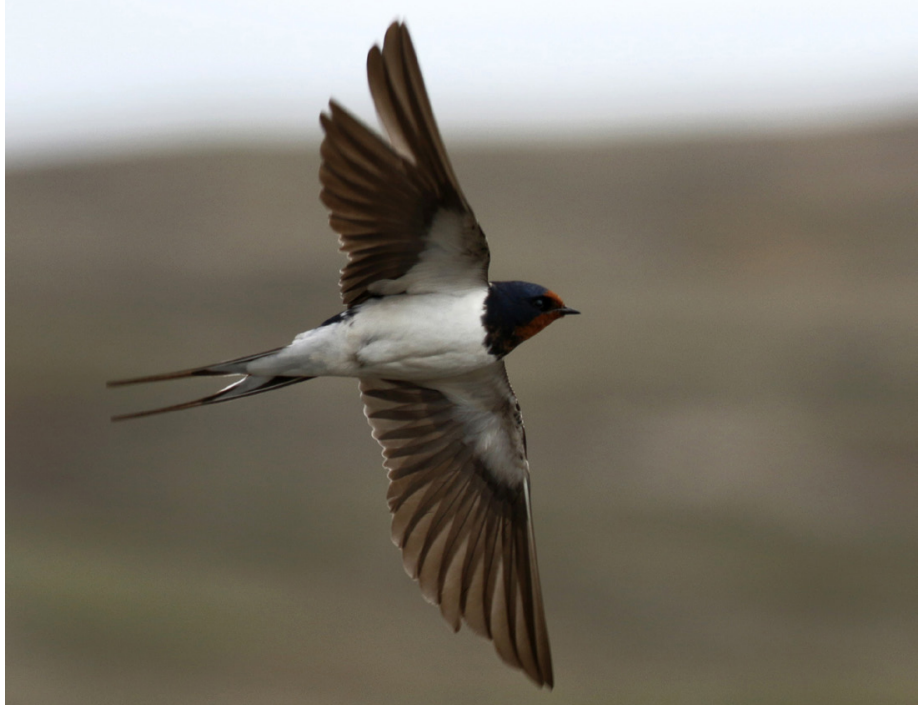

Figure 3. This male Barn Swallow at Qikiqtaruk on 19 and 20 June 2019 was a typical example of $H$. r. rustica, having a bright white underside, thick dark breast band (with just a few scattered rufous feathers), and relatively long tail streamers (though not as long as the bird in Figure 1). See also this issue's inside front cover.

Photo by Cameron D. Eckert

solid blue-black neck band, a relatively limited deep rufous throat patch, and a very long tail (Figure 2). All features of this bird were consistent with nominate rustica. The next day, 25 June 2015, Eckert observed another Barn Swallow that flew through the settlement for less than 30 seconds, though enough time for him to get a good look at the rufous undersides and a broken
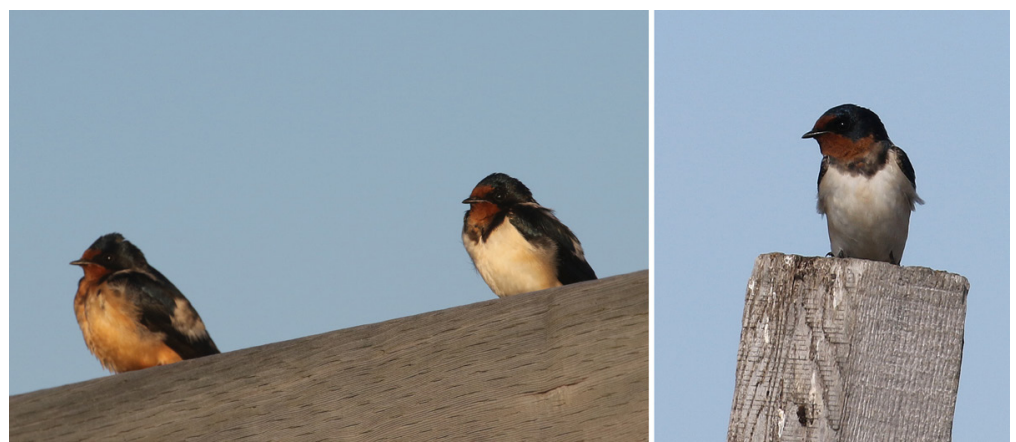

FIgURE 4. A pair of Barn Swallows at Qikiqtaruk on 12 June 2016 included one $H$. $r$. erythrogaster (left) and one individual of uncertain identity (right); the latter showed paler undersides and a slightly broken breast band.

Photos by Cameron D. Eckert 
rufous-washed band identifying the bird as $H$. r. erythrogaster (Table 1). On 19 June 2019, Eckert spotted a white-bellied Barn Swallow along with two individuals of $H$. r. erythrogaster flying around the settlement (Table 1 ). The white-bellied swallow roosted for the night in one of the historic buildings and was seen with the other two birds flying around the settlement the following day. It showed pure white undersides, a thick, unbroken dark blue neck band with just a few rufous feathers, a relatively limited rufous throat patch, and a fairly long though uneven tail, which appeared to be in molt or worn, thereby confirming another occurrence of H. r. rustica at Qikiqtaruk (Figure 3).

Could Barn Swallows nest at Qikiqtaruk? Robinson and DeCicco (2017) noted that artificial structures provide nest sites for the Barn Swallow at the outer peripheries of its range, potentially leading to population shifts. Historic buildings at Qikiqtaruk offer suitable roosting and nesting sites, but when it snows in June or the fog rolls in off the sea ice, as often happens for days, it can mean the sad end for a wayward Barn Swallow. On 12 June 2016, a pair of Barn Swallows arrived at the settlement (Table 1) and flew around feeding for the afternoon; the male was typical H. r. erythogaster, but the other (possibly female) appeared quite pale bellied and its subspecies is uncertain (Figure 4). Two days later Eckert found the male alive but fluttering in the grass. He went to collect maggots from a dead Glaucous Gull to feed it, but by the time he returned the swallow had perished (specimen preserved as catalog number M-28-13 at Yukon College, Whitehorse). So while Qikiqtaruk provides suitable nest sites, the climate on the outer Yukon still likely limits breeding.

\section{BARN SWALLOWS IN THE CANADIAN ARCTIC}

Barn Swallows have been recorded as casual visitants across arctic and subarctic Canada. The most northerly record is from Nasaruvaalik Island $\left(75.8^{\circ} \mathrm{N}, 96.3^{\circ} \mathrm{W}\right)$ in the Canadian Arctic Archipelago (Richards and Gaston 2018). East of the Yukon and Northwest Territories, in Nunavut, Barn Swallows are not of regular occurrence (Richards and Gaston 2018). Across the Canadian Arctic there have been many sightings; the one specimen and four photo-documented records may be evaluated for subspecies (Table 2). Four of the birds are readily identified as H. r. erythrogaster. The one at Southampton Island, Nunavut, on 23 and 25 June 2019 (Table 2) appears to have a white belly but a rufous wash through the front of the breast band and a tail that is not especially long. It could be a female of $H$. $r$. erythrogaster but may be within the range of variation for $H$. r. rustica or gutturalis so we list it here as uncertain.

What route might nominate $H$. r. rustica, which winters in central-southern Africa and breeds in Europe and Iceland (Turner 2006, Brown and Brown 2019), take to reach Qikiqtaruk, some $4500 \mathrm{~km}$ beyond its range? Considering where vagrants of this subspecies have and have not been documented, we propose that they are extreme overshoots, having passed north of Greenland and the Canadian Arctic Archipelago on a polar route direct to the Arctic coast of the Yukon and Alaska (Figure 5). There are few locations along this route where records may be sought, though this hypothesis is supported by a photograph of H. r. rustica at Svalbard, Norway, 23 June 2017 (https://eBird. org/checklist/S37753446), and the complete absence of records to date from 
TABle 2 Specimen- and Photo-Documented Records of the Barn Swallow from the Canadian Arctic and Eastern Subarctic

\begin{tabular}{|c|c|c|c|c|}
\hline Date & Subspecies & Location & Observers & Source ${ }^{a}$ \\
\hline 24 June 1964 & erythrogaster & $\begin{array}{l}\text { Resolute Bay, } \\
\text { Nunavut }\end{array}$ & J. E. Mason & ROM 105507 \\
\hline 12 June 2013 & erythrogaster & $\begin{array}{l}\text { Pond Inlet, } \\
\text { Nunavut }\end{array}$ & $\begin{array}{l}\text { D.-J. Léandri-Breton, } \\
\text { F. Senez-Gagnon }\end{array}$ & S15085271 \\
\hline 15 June 2013 & erythrogaster & $\begin{array}{l}\text { Nasaruvaalik I., } \\
\text { Nunavut }\end{array}$ & I. Pratte & S15247825 \\
\hline 8 June 2017 & erythrogaster & $\begin{array}{l}\text { Paulatuk, North- } \\
\text { west Territories }\end{array}$ & A. Buckley & S37477760 \\
\hline 23-25 June 2019 & uncertain & $\begin{array}{l}\text { Southampton I., } \\
\text { Nunavut }\end{array}$ & $\begin{array}{l}\text { W. English, } \\
\text { A. Lenske, S. Neima }\end{array}$ & S58746341 \\
\hline
\end{tabular}

${ }^{a}$ ROM, Royal Ontario Museum; otherwise, eBird checklist number accessible as "https://ebird. org/checklist/S...."

Newfoundland and Labrador (B. Mactavish pers. comm.). Documenting extralimital birds is a valuable contribution to understanding patterns of vagrancy and inspiring insights into migration and ecological change. The knowledge and tools available to document and share such observations, through https://eBird.org, the Macaulay Library, and www.iNaturalist.org, have never been better.

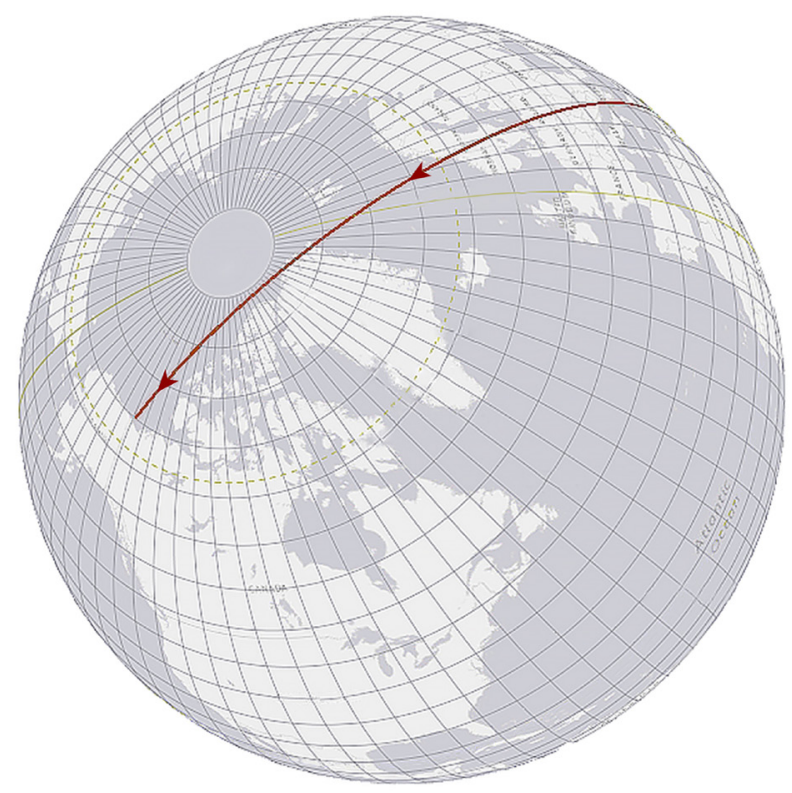

FIGURE 5. The polar route-potential flight path of H. r. rustica flying from its winter range in central Africa, overshooting northern Norway for another $4500 \mathrm{~km}$ to Qikiqtaruk off the Yukon's Arctic coast. 


\section{ACKNOWLEDGMENTS}

We gratefully acknowledge the dedicated support of Herschel Island-Qikiqtaruk Territorial Park's rangers over many years, and the Inuvialuit who welcome visitors to Qikiqtaruk, while ensuring its conservation and protection. Thanks to the many birdwatchers and biologists who report their sightings from across northern Canada and beyond through https://eBird.org, and make their photos available through the Macaulay Library. In particular we thank the following photographers whose material we referenced: Alvan Buckley, Don-Jean Léandri-Breton, Ariel Lenske, Samuel McLeod, LeeJohn Meyook, Isabeau Pratte, and Noah Strycker. This paper benefited from input by Pamela H. Sinclair, Brian Johnston, David M. Bell, Lucas H. DeCicco, Gus B. van Vliet, Bruce MacTavish, Paul E. Lehman, and Royal Ontario Museum curators Santiago Claramunt and Mark Peck. Reviews of the manuscript by Daniel D. Gibson, Steven C. Heinl, and Bryce W. Robinson were much appreciated. Laura Grieve produced the map. The Qikiqtaruk ecological monitoring program is funded by Yukon Parks and Inuvialuit Final Agreement Wildlife Programs as recommended by the Wildlife Management Advisory Council (North Slope).

\section{LITERATURE CITED}

Brown, M. B., and Brown, C. R. 2019. Barn Swallow (Hirundo rustica), in The Birds of North America (P. G. Rodewald, ed.), version 2.0. Cornell Lab Ornithol., Ithaca, NY; doi.org/10.2173/bna.barswa.02

Burn, C. R. (ed.). 2012. Herschel Island-Qikiqtaryuk-A Natural and Cultural History of Yukon's Arctic Island. Univ. Calgary Press, Calgary, AB.

Cooley, D., Eckert, C. D., and Gordon, R. R. 2012. Herschel Island-Qikiqtaruk Inventory, Monitoring, and Research Program: Key findings and recommendations. Yukon Parks, Whitehorse, Yukon; https://wmacns.ca/documents/63/ Herschel_IslandQikiqtaruk_Inventory_Monitoring_and.pdf.

Dickinson, E. C., and Christidis, L. (eds.). 2014. The Howard and Moore Complete Checklist of the Birds of the World, 4th ed., vol. 2: Passerines. Aves Press, Eastbourne, England.

Gibson, D. D., and Withrow, J. J. 2015. Inventory of the species and subspecies of Alaska birds, second edition. W. Birds 46:94-185.

Johnson, S. R., and Herter D. R. 1989. The Birds of the Beaufort Sea. BP Exploration (Alaska) Inc., Anchorage.

Kessel, B., and Gibson, D. D. 1978. Status and distribution of Alaska birds. Studies Avian Biol. 1:1-100.

Lehman, P. E. 2019. The Birds of Gambell and St. Lawrence Island, Alaska. Studies of Western Birds 4. W. Field Ornithol., Camarillo, CA.

Richards, J. M., and Gaston, A. J. (eds.). 2018. Birds of Nunavut, vol. 2: Passerines. Univ. of Br. Columbia Press, Vancouver.

Robinson, B. W., and DeCicco, L. H. 2017. Notes on Eurasian Barn Swallows in Alaska, including the first documentation of successful breeding in North America. W. Birds 48:197-204; doi.org/10.21199/WB48.3.4.

Sinclair, P. H., Nixon, W. A., Eckert, C. D., and Hughes, N. L. (eds.). 2003. Birds of the Yukon Territory. Univ. of Br. Columbia Press, Vancouver.

Turner, A. 2006. The Barn Swallow. Poyser, London.

Turner, A. and Rose, C. 1989. A Handbook to the Swallows and Martins of the World. Christopher Helm, London.

Zink, R. M., Pavlova, A., Rohwer, S., Drovetski, S. V. 2006. Barn Swallows before barns: Population histories and intercontinental colonization. Proc. R. Soc. B 273:1245-1251; doi.org/10.1098/rspb.2005.3414. 